\title{
Characterization and risk factors for pressure ulcers in the hospitalized elderly*
}

\author{
Caracterização e fatores de risco para úlceras por pressão na pessoa idosa hospitalizada \\ Caracterización y factores de riesgo para úlceras por presión en la persona anciana \\ hospitalizada
}

Chrystiany Plácido de Brito Vieira ${ }^{1}$, Mirtes Sousa Sá ${ }^{1}$, Maria Zélia de Araújo Madeira ${ }^{1}$, Maria Helena Barros Araújo Luz ${ }^{1}$

This study aimed to identify the socio-demographic and clinical characteristics; obtain the risk factors for pressure ulcers identified in hospitalized senior citizens. This is a prospective, descriptive, and quantitative study. The sample consisted of 215 hospitalized elderly people in a public hospital in Teresina, PI, Brazil, in orthopedic, neurological, medical, and surgical clinics, and Intensive Care Units from November/2012 to February/2013. Data collection happened through interviews, physical examinations, and medical records. The average age was 71.8 years old, most patients were female (55.3\%), with low education, and married. The majority were taken into orthopedics (42.3\%). For the length of hospital stay, the average was of 12.4 days. The most prevalent risk factors were hypertension, use of analgesics, antihypertensives, and anticoagulants. Eighty-seven senior citizens (40.5\%) presented low risk. One highlights the importance of nursing care in the prevention and assessment of risk for pressure ulcers in order to reduce its incidence in hospitals.

Descriptors: Aged; Pressure Ulcer; Risk Factors; Nursing.

Objetivou-se identificar características sociodemográficas e clínicas; levantar os fatores de risco para úlceras por pressão identificadas em idoso hospitalizado. Estudo de coorte prospectivo, descritivo e quantitativo. A amostra foi composta por 215 pessoas idosas internadas em hospital público de Teresina, PI, Brasil, nas clínicas ortopédicas, neurológica, médica, cirúrgica e Unidades de Terapia Intensiva, de novembro/2012 a fevereiro/2013, utilizando-se para coleta de dados entrevista, exame físico e prontuário. A média de idade foi de 71,8 anos, maioria do sexo feminino (55,3\%), com baixa escolaridade e casada. A maioria se encontrava internada na ortopedia (42,3\%). Média de internação de 12,4 dias. Os fatores de risco mais prevalentes foram hipertensão arterial e uso de medicações como analgésicos, anti-hipertensivos e anticoagulantes. Baixo risco foi apresentado por 87 (40,5\%) idosos. Destaca-se a importância da assistência de enfermagem na prevenção e avaliação do risco para úlcera por pressão para redução da incidência desta em hospitais.

Descritores: Idoso; Úlcera por Pressão; Fatores de Risco; Enfermagem.

El objetivo fue identificar características sociodemográficas y clínicas; señalar los factores de riesgo para úlceras por presión en anciano hospitalizado. Estudio de cohorte prospectivo, descriptivo y cuantitativo. Muestra de 215 ancianos ingresados en hospital público de Teresina, PI, Brasil, en las clínicas de ortopedia, unidades de cuidados médicos, quirúrgicos, neurológicos e intensivos de noviembre/2012 a febrero/2013, utilizándose recopilación de datos entrevista, examen físico y registros médicos. La edad promedia fue de 71,8 años, mayoría mujeres (55,3\%), con bajo nivel de estudios y casada. La mayoría fue internada en traumatología (42,3\%). Estancia hospitalaria media de 12,4 días. Los factores de riesgo más prevalentes fueron hipertensión y uso de medicaciones, como analgésicos, antihipertensivos y anticoagulantes. Bajo riesgo fue presentado por 87 (40,5\%) ancianos. Se destaca la importancia de la atención de enfermería en la prevención y evaluación de riesgos para úlceras por presión para reducir la incidencia de estas en hospitales.

Descriptores: Anciano; Úlcera por Presión; Factores de Riesgo; Enfermería.

\footnotetext{
*Extracted from the end-of-course paper "Incidence and Risk Factors for pressure ulcers in the hospitalized elderly", from the Nursing Undergraduate Course from the Universidade Federal do Piauí, 2013.

${ }^{1}$ Universidade Federal do Piauí. Teresina, PI, Brazil.

Corresponding author: Chrystiany Plácido de Brito Vieira

Rua Anfrísio Lobão, 1235, Condomínio Mansão Rino Levi, Apt.501, Jóckey. CEP: 64.049-280. Teresina, PI, Brazil. E-mail: chrystianyplacido@ yahoo.com
} 


\section{Introduction}

Pressure ulcers are problems faced by professionals and health services for intensifying the costs of the sector and due to the physical, emotional and social repercussions to the patient and the family, affecting greatly their quality of life.

This injury also increases the risk of infection and sepsis, which, besides prolonging hospitalization and increasing the total costs with care to the patient, aggravates the mortality rate ${ }^{(1)}$.

Thus, pressure ulcers were included as an indicator of quality of care provided by health services, noting the importance and need for further research regarding its incidence and national prevalence. However, the problem of pressure ulcers goes beyond the assistance provided by a particular professional category, such as nursing care, whose performance represents a key role in the process of prevention and treatment of this injury, which aims to reduce the length of hospital stay and hence costs in the treatment, improving the prognosis and preventing infections ${ }^{(2)}$.

Hence, the quality indicators can monitor assistance and evaluate the impact of nursing actions in the care process of hospitalized patients in order to enable the improvement of this care, and when the levels of incidence of pressure ulcers become low, they will indicate effective nursing care ${ }^{(3)}$.

There are predisposing factors for the occurrence of pressure ulcers: immobility, impaired sensory perception, tissue perfusion and decreased nutritional status, frictional forces and shear, exposure to moisture, skin changes associated with aging. As risk factors for pressure ulcers: prolonged pressure on the tissue; immobility, impaired mobility; loss of protective reflexes, sensory deficit; poor skin perfusion, edema; malnutrition, hypoproteinemia, anemia, vitamin deficiency; friction, shearing forces, trauma; incontinence of urine and feces; altered skin moisture, being excessively dry or humid; advanced age, debilitation; equipment such as plaster, traction and retainers ${ }^{(4)}$.
The risk factors that cause the appearance of pressure ulcers can be intrinsic or extrinsic, and the first factors are four: prolonged pressure on the tissue, friction, shear and moisture. The seconds factors are age, reduced sensitivity, immobility, altered level of consciousness, disturbances and nutritional changes, such as obesity and the presence of chronic diseases such as cerebrovascular accidents and systemic arterial hypertension ${ }^{(5)}$.

Another external risk factor is the use of medications that can have direct influence on the occurrence of pressure ulcers due to systemic changes that cause severe reactions in the human body, such as analgesics, antihypertensives and anticoagulants ${ }^{(6)}$.

Considering that the treatment of the lesion is costly and laborious, one notes the importance for nurses of acquiring specific knowledge and skills to assess the problem and the responsibility to identify early those patients with obvious risk of developing pressure ulcers, as in groups considered more vulnerable, such as the elderly, especially those who are institutionalized, so that preventive measures are taken immediately.

In Brazil, the elderly represent a substantial population group with growing importance in the overall Brazilian society, and with it, they demand a lot of care $^{(7)}$.

The elderly have predisposing conditions for the development of pressure ulcers, which are caused by the very effect of aging on the human body, such as decreased dermal thickness, reduction in the number of elastic fibers and process of collagen rigidity, reduction of subcutaneous adipose tissue mainly in the limbs, reduction of capillaries in the skin, resulting in reduced blood supply and drying of the skin which makes it more susceptible to injuries ${ }^{(4)}$.

Associated with this, the elderly are predisposed to chronic noncommunicable diseases, which can interfere in their perceptual capacity, blood circulation, oxygenation, mobility, level of consciousness, changes in the levels of electrolytes and proteins that lead to hospitalization. In addition, they increase significantly 
the chances of complications in their clinical status for raising the length of hospital stay, which predisposes the occurrence of pressure ulcers.

Some chronic noncommunicable diseases are prevalent in the elderly population as cerebrovascular accident and systemic arterial hypertension, and many times, besides causing immobilization in bed, deficient nutritional status and pressure on bony prominences, they are frequent causes of impaired skin integrity of the elderly ${ }^{(6)}$.

In this context, the daily assessment of an elderly person by nurses and the implementation of effective preventive measures become essential due to the multiple causes of this disease. Such care must be performed by nurses who must have knowledge about the risk factors and complications of pressure ulcers, the classification of the dependence degree and the prescription of necessary care in order to prevent the development of this lesion.

Hence, considering the importance of this theme as an indicator of the quality of nursing care and considering the population growth of the elderly and their vulnerability to develop pressure ulcers, this study aimed to identify their sociodemographic and clinical characteristics and raise the risk factors for pressure ulcers identified in the hospitalized elderly.

\section{Method}

This is a prospective cohort study, of descriptive nature, with quantitative data analysis, performed in a general teaching hospital of the large city of Teresina, Piauí, in neurological, medical, orthopedic and surgical clinics and in Intensive Care Units.

The sample consisted of 215 elderly people, distributed in places of internment defined in the study and who met the following inclusion criteria: being admitted in these sectors under study during the period of data collection and being 60 years old or older. As the exclusion criteria, one defined the hospital stay of less than 48 hours.
Data collection was conducted from November 2012 to February 2013, through interviews, using as an instrument a semi-structured questionnaire applied to the elderly people or the caregiver in charge, if the old person did not have conditions to answer the questions asked, and supplemented by information obtained by their physical examination and medical records. At the time of the interview the Braden Scale was applied for determining the risk score, which was considered the value of 18 or less for risk characterization.

One used the software Statistical Package for the Social Sciences for Windows (version 17.0), to organize and analyze the data. The quantitative variables were presented through descriptive (average, standard deviation) and qualitative statistics through ratio and confidence interval (95\%). First, the KolmogorovSmirnov test was used to evaluate the normality of the quantitative variables. Since the variables did not follow the tendency to normality, nonparametric tests were used. The analysis of the reliability of the Braden scale was performed through the Cronbach's alpha coefficient. To analyze the difference between two averages, the Mann-Whitney test was used.

This study was submitted to the Ethics Committee in Research of the institution for obtention of institutional authorization and then to the Ethics Committee of the Federal University of Piauí, receiving favorable opinion No. 91,109 from 09/05/2012, in accordance with Resolution 466/12.

\section{Results}

The study included 215 elderly people. The age ranged from 60 to 98 years old, with average $71.8 \pm 8.8$, with a prevalence in the age group from 60 to 70 years old; there was a predominance of females, 119 (55.3\%). Regarding their origin, 76 (35.3\%) were from Teresina and 118 (54.9\%) from the countryside. Regarding education, the majority, 143 (66.5\%) had no schooling, with average years of schooling of $1.7 \pm 3.1$. Concerning the variable marital status, 108 (50.2\%) 
were married, followed by widowed, 68 (31.6\%). The family income of the majority, $123(57.2 \%)$ were two monthly minimum wages.

Table 1 - Characterization of the population regarding age, gender, birthplace, education, marital status and family income. $(n=215)$

\begin{tabular}{lc}
\hline Variables & $\mathbf{n}(\%)$ \\
\hline Age group (years) & $101(47.0)$ \\
$60-70$ & $65(30.2)$ \\
$70-80$ & $42(19.5)$ \\
$80-90$ & $7(3.3)$ \\
$\geq 90$ & $71.8(8.8)$ \\
Average (SD) & \\
Gender & $119(55.3)$ \\
Female & $96(44.7)$ \\
Male & \\
Birthplace & $76(35.3)$ \\
Teresina & $118(54.9)$ \\
Other cities & $21(9.8)$ \\
Other states & \\
Education & $143(66.5)$ \\
No education & $62(28.8)$ \\
Elementary Education & $4(1.9)$ \\
High School & $6(2.8)$ \\
Higher Education & $1.7(3.1)$ \\
Average (SD) & \\
Marital Status & $21(9.8)$ \\
Single & $108(50.2)$ \\
Married & $12(5.6)$ \\
Divorced & $6(2.8)$ \\
Stable union & $68(31.6)$ \\
Widowed & \\
Family income (MW*) & $86(40.0)$ \\
1 & $123(57.2)$ \\
2 & $6(2.8)$ \\
\hline MW: Minimum Wage in March $2013(\mathrm{R} \$=622.00$ or US\$=313.66) \\
\end{tabular}

Table 2 shows the results of the clinical characterization of the population studied. It was observed that 91 (42.3\%) were hospitalized in orthopedic clinics, $49(22.8 \%)$ in the surgical I, 27 $(12.6 \%)$ in the intensive care unit, $27(12.6 \%)$ in neurological and 21 (9.8\%) in medical clinics. The hospitalization time was high, with an average of 12.4 \pm 9.9 . The majority, $139(64.7 \%)$ had surgical diagnosis and $151(70.2 \%)$ were using medication continuously.
Table 2 - Clinical characterization of the population of the study. $(\mathrm{n}=215)$

\begin{tabular}{lc}
\hline Variables & $\mathbf{n}(\%)$ \\
\hline Place of hospitalization & $21(9.8)$ \\
Medical Clinic & $27(12.6)$ \\
Neurological Clinic & $91(42.3)$ \\
Orthopedic Clinics & $49(22.8)$ \\
Surgical Clinic I & $27(12.6)$ \\
Intensive Care Units & \\
Length of hospital stay (days) & $115(53.5)$ \\
$\leq 10$ & $68(31.6)$ \\
$11-20$ & $23(10.7)$ \\
$21-30$ & $9(4.2)$ \\
$>30$ & $12.4(9.9)$ \\
Average (SD) & \\
Diagnosis & $76(35.3)$ \\
Clinical & $139(64.7)$ \\
Surgical & \\
Medications of continuous use & $151(70.2)$ \\
Yes & $64(29.8)$ \\
No & \\
\hline
\end{tabular}

Concerning the medications of continuous use reported by the elderly population studied, one highlighted the use of antihypertensive drugs by $82.8 \%$, followed by the use of other medications by $15.0 \%$.

The most prevalent diagnoses were found in the musculoskeletal, nervous, cardiovascular and hepatic systems, with 108 (50.2\%), 33 (15.3\%), 28 (13.0\%) and 17 (7.9\%) cases, respectively.

On table 3 , there are data about the risk factors in each clinic investigated. It was found that in all the clinics the most prevalent risk factors were having non-communicable chronic diseases, in this case hypertension, and medication use, especially analgesics, antihypertensives and anticoagulants. In the neurologic clinic, one adds the factors same position for more than two hours and folds in bedding that leave marks on the body.

At the orthopedic clinic, among the risk factors analyzed, one also highlighted the presence of decreased turgor and elasticity as facilitators for the occurrence of pressure ulcers in the respondents. 
Table 3 - Risk factors for the development of pressure ulcers in the study population. $(n=215)$

\begin{tabular}{|c|c|c|c|c|c|c|}
\hline \multirow[t]{2}{*}{ Risk factors } & Medical & Neuro & Orthopedic & Surgical I & $\begin{array}{c}\text { Intensive Care } \\
\text { Unit } \\
\end{array}$ & Total \\
\hline & n (\%) & n (\%) & n (\%) & n (\%) & n (\%) & $\mathbf{n}$ \\
\hline \multicolumn{7}{|c|}{ Diabetes mellitus } \\
\hline No & $20(95.2)$ & $23(85.2)$ & $80(87.9)$ & $38(77.6)$ & $21(77.8)$ & 182 \\
\hline Yes & $1(4.8)$ & $4(14.8)$ & $11(12.1)$ & $11(22.4)$ & $6(22.2)$ & 33 \\
\hline \multicolumn{7}{|c|}{ Arterial hypertension } \\
\hline No & $9(42.9)$ & $12(44.4)$ & $43(47.3)$ & $16(32.7)$ & $10(37.0)$ & 90 \\
\hline Yes & $12(57.1)$ & $15(55.6)$ & $48(52.7)$ & $33(67.3)$ & $17(63.0)$ & 125 \\
\hline \multicolumn{7}{|c|}{ Other diseases } \\
\hline No & $14(66.7)$ & $26(96.3)$ & 77 (84.6) & $44(89.8)$ & $24(88.9)$ & 185 \\
\hline Yes & $7(33.3)$ & $1(3.7)$ & $14(15.4)$ & $5(10.2)$ & $3(11.1)$ & 30 \\
\hline \multicolumn{7}{|l|}{ No diseases } \\
\hline No & $15(71.4)$ & $16(59.3)$ & $59(64.8)$ & $35(71.4)$ & $20(74.1)$ & 145 \\
\hline Yes & $6(28.6)$ & $11(40.7)$ & $32(35.2)$ & $14(28.6)$ & $7(25.9)$ & 70 \\
\hline \multicolumn{7}{|l|}{ Analgesic } \\
\hline No & $1(4.8)$ & $1(3.7)$ & $3(3.3)$ & $3(6.1)$ & $5(18.5)$ & 13 \\
\hline Yes & $20(95.2)$ & $26(96.3)$ & $88(96.7)$ & $46(93.9)$ & $22(81.5)$ & 202 \\
\hline \multicolumn{7}{|c|}{ Antihipertensive } \\
\hline No & $11(52.4)$ & $13(48.1)$ & $44(48.4)$ & $15(30.6)$ & $13(48.1)$ & 96 \\
\hline Yes & $10(47.6)$ & $14(51.0)$ & 47 (51.6) & $34(69.4)$ & 14 (51.9) & 119 \\
\hline \multicolumn{7}{|l|}{ Anticoagulant } \\
\hline No & $8(38.1)$ & $9(33.3)$ & $34(37.4)$ & $24(49.0)$ & $11(40.7)$ & 86 \\
\hline Yes & $13(61.9)$ & $18(66.7)$ & $57(62.6)$ & $25(51.0)$ & $16(59.3)$ & 129 \\
\hline \multicolumn{7}{|l|}{ Antibiotic } \\
\hline No & $16(76.2)$ & $22(81.5)$ & $64(70.3)$ & $34(69.4)$ & $19(70.4)$ & 155 \\
\hline Yes & $5(23.8)$ & $5(18.5)$ & 27 (29.7) & $15(30.6)$ & $8(29.6)$ & 60 \\
\hline \multicolumn{7}{|l|}{ Smoking } \\
\hline No & $21(100.0)$ & $23(85.2)$ & 72 (79.1) & $42(85.7)$ & $23(85.2)$ & 181 \\
\hline Yes & - & $4(14.8)$ & $19(20.9)$ & $7(14.3)$ & $4(14.8)$ & 34 \\
\hline \multicolumn{7}{|l|}{ Drinking } \\
\hline No & $21(100.0)$ & $24(88.9)$ & $82(90.1)$ & 47 (95.9) & 27 (100.0) & 201 \\
\hline Yes & - & $3(12.0)$ & $9(9.9)$ & $2(4.2)$ & - & 14 \\
\hline \multicolumn{7}{|l|}{ Dry skin } \\
\hline No & $17(81.0)$ & $24(88.9)$ & $62(68.1)$ & $39(79.6)$ & $21(77.8)$ & 163 \\
\hline Yes & $4(19.0)$ & $3(11.1)$ & $29(31.9)$ & $10(20.4)$ & $6(22.2)$ & 52 \\
\hline \multicolumn{7}{|c|}{ Decreased turgor/Elasticity } \\
\hline No & $16(76.2)$ & $18(72.0)$ & $44(48.4)$ & $25(51.0)$ & $16(59.3)$ & 119 \\
\hline Yes & $5(23.8)$ & 09 (33.3) & 47 (51.6) & $24(49.0)$ & $11(40.7)$ & 96 \\
\hline \multicolumn{7}{|c|}{ Previous ulcers } \\
\hline No & $21(100.0)$ & $19(70.4)$ & $86(94.5)$ & $46(93.9)$ & $25(92.6)$ & 197 \\
\hline Yes & - & $8(26.9)$ & $5(5.5)$ & $3(6.1)$ & $2(7.4)$ & 18 \\
\hline \multicolumn{7}{|l|}{ Same position } \\
\hline No & $13(61.9)$ & $13(48.1)$ & $53(58.2)$ & $33(67.3)$ & $15(55.6)$ & 127 \\
\hline Yes & $8(38.1)$ & $14(51.9)$ & $38(41.8)$ & $16(32.7)$ & $12(44.4)$ & 88 \\
\hline \multicolumn{7}{|c|}{ Folds in clothes } \\
\hline No & $15(71.4)$ & $13(48.1)$ & $62(68.1)$ & $31(63.3)$ & $16(59.3)$ & 137 \\
\hline Yes & $6(28.6)$ & $14(51.9)$ & $29(31.9)$ & $18(36.7)$ & $11(40.7)$ & 78 \\
\hline \multicolumn{7}{|c|}{ Elevation in the bed $>30^{\circ}$} \\
\hline No & $19(90.5)$ & $23(85.1)$ & $76(83.5)$ & $45(91.8)$ & $22(81.5)$ & 185 \\
\hline Yes & $2(9.5)$ & $4(14.8)$ & $15(16.5)$ & $4(8.2)$ & $5(18.5)$ & 30 \\
\hline \multicolumn{7}{|l|}{ Bedrest } \\
\hline No & $13(61.9)$ & $14(51.9)$ & $50(54.9)$ & $35(71.4)$ & $14(51.9)$ & 126 \\
\hline Yes & $8(38.1)$ & $13(48.1)$ & $41(45.1)$ & $14(28.6)$ & $13(48.1)$ & 89 \\
\hline
\end{tabular}


In the classification of the risk degree for the Braden Scale, it was found that the majority, $114(53.0 \%)$ of the respondents were not at risk of developing pressure ulcers, with a confidence interval of 42.5 to 63.5 (Table 4 ).

Table 4 - Classification of the Braden Scale in research participants and their respective confidence intervals. $(\mathrm{n}=215)$

\begin{tabular}{lcc}
\hline Braden Scale & n (\%) & Confidence Interval 95\% \\
\hline No risk & $114(53.0)$ & $42.5 ; 63.5$ \\
Low risk & $87(40.5)$ & $13.8 ; 67.1$ \\
Moderate risk & $13(6.0)$ & $0.7 ; 52.8$ \\
High risk & $1(0.5)$ & $-0.4 ; 1.4$ \\
\hline
\end{tabular}

Table 5 contains the verification of the reliability of the Braden scale through the Cronbach's alpha coefficient, which has variation from 0 to 1 . The $\alpha$ value of global Cronbach and the values obtained, in case each individual item was deleted from the scale, demonstrates the level of correlation between them. The global coefficient found was 0.821 .

Table 5 - Analysis of internal consistency (Cronbach's alpha) of the Braden Scale. ( $\mathrm{n}=215)$

\begin{tabular}{lccc}
\hline Braden Scale & $\begin{array}{c}\text { Average } \\
\text { (SD) }\end{array}$ & $\begin{array}{c}\text { Component } \\
\text { x Total* }^{*}\end{array}$ & $\begin{array}{c}\text { Alpha without } \\
\text { the component** }\end{array}$ \\
\hline Sensory perception & $3.95(0.3)$ & 0.707 & 0.737 \\
humidity & $3.64(0.7)$ & 0.741 & 0.688 \\
Activity & $2.33(1.4)$ & 0.733 & 0.716 \\
Mobility & $3.27(0.9)$ & 0.737 & 0.705 \\
Nutrition & $3.08(0.4)$ & 0.706 & 0.726 \\
Friction & $2.66(0.6)$ & 0.731 & 0.701 \\
Global Cronbach's & & & \\
alpha coefficient & & \\
*Value obtained without removing none of the items from the scale \\
***alue obtained if the corresponding item was eliminated from the scale
\end{tabular}

\section{Discussion}

The high average age of the elderly who participated in the research and the predominance of females show an increase in life expectancy of the Brazilian population, caused by the processes of demographic and epidemiological transition the population is going through. These data are supported by research that confirms the increase in life expectancy at birth to 74.08 years, in which most of the elderly are women (55.7\%), with a life expectancy of 77 years of age for them, and for men of 70.6 years ${ }^{(8)}$.

Reaching the old phase of life is a population reality even in the poorest countries, and in Brazil this process has been happening very rapidly. Every year the country adds 650 thousand new senior citizens to the population, a reality that entails a number of crucial issues for managers and researchers in the field of health and impacts on society in general, because of social inequalities, poverty and institutional fragility ${ }^{(9)}$.

Low education presented by the majority of the study participants reflects the level of education of this population and their poor access to information, which can compromise the quality of life of these people. Knowing their schooling, and their marital status is important to verify the relationship between the educational aspect, the social life and the emotional aspects with the health indicators in the elderly population and hence their tendency to illness and loss of functional capacity ${ }^{(6)}$.

The household income of most respondents was two minimum wages. It is reiterated that $21.9 \%$ of people responsible for the household are aged, with a direct relationship of family income to their health status $^{(7)}$.

Regarding the place of internment, the majority of respondents were in orthopedic clinics, a fact that is associated with increased risk of falls and fractures of the elderly. Some intrinsic factors of the elderly that favor the occurrence of trauma, such as losses due to physiological decline that accompany the aging process, are alterations in the cardiac, nervous, sensory and musculoskeletal systems, being highlighted the alterations in vision, hearing, smell, gait, balance, coordination and reaction time.

When one verified the diagnoses of the elderly, 
it was found that the predominant ones were related to musculoskeletal system, diagnoses directly related to fractures, especially of the femur. The femur fracture represented $67.6 \%$ of the fractures presented by the study participants who were hospitalized in the orthopedic clinics. A femur fracture is a cause of mortality and functional loss among older people, besides causing high social cost, as there is often the need of intensive medical care and rehabilitation programs for a prolonged period ${ }^{(10)}$.

Another study reveals that the number of hospital admissions for femur fractures and other bones of the limbs is higher in older people and that the cost of treatment is very high. Furthermore, it shows that disability increases with age and that there is a statistical association between greater functional impairment and longer hospitalization ${ }^{(11)}$.

Regarding the time of admission, it was found a high average, different from the one found in other studies $^{(10,12)}$ that noted length of stay of 10 and 9.1 days, then lower than the one found in the present study. Adding to this situation, most of the hospital beds are occupied by older people who are more vulnerable to reduced mobility, mental confusion, depression, hospital infection and malnutrition. Considering the above and the aged person, the average of hospital stay in this study was high, and even more significant when combined with the theme of pressure ulcers, whose estimated occurrence time is of 24 hours and may take up to five days, both shorter than the average length of stay found.

A prolonged period of hospitalization is worrisome when it comes to elderly people, considering the possibility of complications and, especially, functional decline, to which these patients are vulnerable. Moreover, this relationship between functional capacity and length of stay reflects the quality of hospital services offered, taking into account specialized and rehabilitation assistance ${ }^{(10)}$.

Therefore, one of the results of population's aging process is the bigger demand of health services by the elderly population, more hospitalizations and hospital bed occupancy when compared to the younger population ${ }^{(9)}$.

Regarding risk factors for the occurrence of pressure ulcers, it is noteworthy that among the groups of patients, the elderly have higher risk for the development of the lesion, which can be explained by the aging process itself, responsible for changes in the skin and subcutaneous tissues, and cardiovascular changes caused by noncommunicable chronic diseases. These diseases that can alter blood circulation, level of consciousness and oxygenation, and therefore impair the healing of the skin, reducing its resistance to damage by the weakness caused by such changes ${ }^{(6)}$.

In this situation, the chronic noncommunicable diseases are characterized by the advent of complications which, in more debilitated patients, increases the risk of developing pressure ulcers. Thus, it requires a strict control scheme and permanent care because of the possible consequences, which can result in functional impairment. To do so, nursing care and the use of strategies to enable the elderly to maintain functional capacity are paramount in order to prevent lesions $^{(13)}$.

In all the clinics, the most prevalent risk factors among participants were having the grievance arterial hypertension and using medications such as analgesics, antihypertensives and anticoagulants. About the continuous use of medication, another study also noted as significant for the formation of pressure ulcers the use of analgesics in $60 \%$ of patients, antihypertensive drugs by $50 \%$ and anticoagulants for $75 \%$ of the affected people, in addition to antibiotics, by $85 \%$ of these patients ${ }^{(14)}$.

Continued use of antihypertensive reduces blood flow and tissue perfusion, which makes patients more susceptible to pressure, facilitating the development of pressure ulcers ${ }^{(15)}$.Another medication also used by most respondents was the analgesic, a drug that causes a reduction in the natural stimulus for position change to a nuisance and consequent reduction of pressure relief, thus facilitating the 
development of the lesion. The development of pressure ulcers is therefore a complex phenomenon that involves factors related to the patient and to the external environment ${ }^{(16)}$.

In the neurological and orthopedic clinics, besides these factors, one observed peculiarities, in the first one added up the factors same position for more than two hours and folds in bedding that leave marks on the body. In the second, one added up decreased turgor and elasticity. These factors had been identified in other studies as risk factors for the development of the lesion ${ }^{(6,14)}$.

According to the Braden scale, most participants did not have risk for developing pressure ulcers. However, it is still significant the percentage (47\%) of respondents who reached Braden score less than or equal to 18 , thus indicating risk for development of the lesion.

One could observe the high reliability of Braden in this study, ie, the instrument used in the research could infer or measure what was actually proposed, giving relevance to the research, according to the outcome of the values resulting from the analysis of internal consistency.

This study probably had some limitations and difficulties, related to the fact that it is an end-ofcourse paper which did not allow more time to collect more clinical data; to the lack of systematic records in the medical records about the clinical conditions of the elderly, which brings to light the need for development of evaluation plans for the development of preventive and therapeutic care systems.

\section{Conclusions}

Knowing the profile of hospitalized elderly, as well as the clinical conditions presented and detect the risk factors makes it easier the elaboration and systematization of preventive nursing actions in relation to the occurrence of pressure ulcers. Among the risk factors identified in this study, it must be recognized that the occurrence of lesions in this population is associated, probably, to changes of aging itself, the use of medications such as analgesics, antihypertensives and anticoagulants, as well as diseases such as hypertension detected in this study. Other factors should also be highlighted, for being present in the context of these patients, like folds in bedding, decreased turgor and elasticity.

One reiterates that the health/nursing team needs to review and implement simple measures for the relief of pressure, facilitation and stimulation of feeding and hydration, as well as prevention and control of chronic diseases and supervision of the skin of elderly patients who use medications such as antihypertensives, anticoagulants and analgesics.

This study, therefore, reached the proposed objectives despite difficulties and limitations in relation to the short time of data collection and lack of systematic records in the medical charts. This study allows one to extend the evidence for nursing care, contributing to systematic procedures in determining risk factors for pressure ulcers in the population of the hospitalized elderly, because when one detects the risk factors, it becomes easier to systematize nursing actions aimed at preventing these events.

\section{Collaborations}

Vieira CPB contributed to the study design, literature review, data analysis and writing of the article. Sá MS contributed to the study design, literature review, data collection and analysis and writing of the article. Madeira MZA contributed to the critical revision and final editing of the article. Luz MHBA contributed to the critical revision and final editing of the article. All the authors contributed to the critical revision and approval of the version to be published.

\section{References}

1. Moraes GLA, Araújo TM, Caetano JA, Lopes MVO, Silva MJ. Evaluation of the risk for pressure ulcers 
in bedridden elderly at home. Acta Paul Enferm. 2012; 25(n.esp):7-12.

2. Rolim JA, Vasconcelos JMB, Caliri MHL, Santos IBC. Prevention and treatment of pressure ulcers in the daily lives of intensivist nurses. Rev Rene. 2013; 14(1):148-57.

3. Moura GMSS, Juchem BC, Falk MLR, Magalhães AMM, Suzuki LM. Construção e implantação de dois indicadores de qualidade assistencial de enfermagem. Rev Gaúcha Enferm. 2009; 30(1):136-40.

4. Smeltzer SC, Bare BG. Brunner \& Suddarth: Tratado de Enfermagem Médico-Cirúrgica. 11aㅡ ed. Rio de Janeiro: Guanabara Koogan; 2009.

5. Irion G. Feridas: novas abordagens, manejo clínico e atlas em cores. Rio de Janeiro: Guanabara Koogan; 2005.

6. Freitas MC, Medeiros ABF, Guedes MVC, Almeida PC, Galiza FT, Nogueira JM. Úlcera por pressão em idosos institucionalizados: análise da prevalência e fatores de risco. Rev Gaúcha Enferm. 2011; 32(1):143-50.

7. Instituto Brasileiro de Geografia e Estatística. Síntese de indicadores sociais: uma análise das condições de vida da população brasileira. Rio de Janeiro: IBGE; 2010.

8. Instituto Brasileiro de Geografia e Estatística. Síntese de Indicadores Sociais 2012 [Internet] 2012 [citado 2013 mar 24]. Disponível em: http://www.ibge.gov.br/home/presidencia/ noticias/noticia_impressao.php?id_noticia $=2268$.

9. Veras R. Envelhecimento populacional contemporâneo: demandas, desafios e inovações. Rev Saúde Pública. 2009; 43(3):548-54.

10. Monteiro CR, Faro ACME. Functional evaluation of aged with fractures at hospitalization and at home. Rev Esc Enferm USP. 2010; 44(3):719-24.

11. Maciel SSSV, Maciel WV, Lima Neto AJ, Santos FJF, Sobral HV, Sobral LV. Internação hospitalar por fraturas de fêmur e outros ossos dos membros em residentes de Pernambuco. Rev AMRIGS. 2012; 56(3):213-9.

12. Silva DP, Barbosa MH, Araújo DF, Oliveira LP, Melo AF. Úlcera por pressão: avaliação de fatores de risco em pacientes internados em um hospital universitário. Rev Eletr Enf [periódico na Internet] 2011 [citado 2013 mar 24]; 13(1):11823. Disponível em: www.fen.ufg.br/fen_revista/ v13/n1/pdf/v13n1a13.pdf

13. Contiero AP, Pozarti MPS, Challouts RI, Carreira L, Marcon SS. Idoso com hipertensão arterial: dificuldades de acompanhamento na estratégia saúde da família. Rev Gaúcha Enferm. 2009; 30(1):62-70.

14. Furman GF, Rocha AF, Guariente MHDM, Barros SKSA, Morooka M, Mouro DL. Pressure ulcers: incidence and associated risk factors in patients of a university hospital. Rev Enferm UFPE online. [periódico na Internet] 2010 [cited $2013 \mathrm{Mar}$ 24]; 4(3):1506-14. Available from: http://www. revista.ufpe.br/revistaenfermagem/index.php/ revista/article/viewArticle/1148

15. Sayar S, Turgut S, Doğan H, Ekici A, Yurtsever S, Demirkan $F$ et al. Incidence of pressure ulcers in intensive care unit patients at risk according to the Waterlow scale and factors influencing the development of pressure ulcers. J Clin Nurs. 2009; 18(5):765-74.

16. Anders J, Heinemann A, Leffmann C, Leutenegger M, Pröfener F. Decubitus Ulcers: pathophysiology and primary prevention. Dtsch Arztebl Int. 2010; 107(21):371-8. 